\title{
PEMERANAN TOKOH AKU DALAM NASKAH MY FRIEND HAS COME KARYA TOSHIRO SUZUE
}

\author{
Rangga Dwi Apriadinnur \\ Institut Seni Indonesia Yogyakarta
}

\begin{abstract}
Abstrak: My Friend Has Come menceritakan tokoh Aku yang memiliki keunikan psikologis dan sosiologis. Tokoh Aku adalah seorang introvert dengan kecenderungan skizofrenia. Dalam cerita, ia juga dikatakan sebagai hikikomori, sebutan dalam Bahasa Jepang terhadap orang yang melakukan penarikan diri dari interaksi sosial. Untuk memahami dan memerankan tokoh $\mathrm{Aku}$ ini, penulis melakukan penelitian kualitatif dengan studi pustaka tentang psikologi, hikikomori, dan juga menonton referensi lain dengan tokoh serupa dengan tokoh Aku. Penulis menggunakan metode pendekatan Magic If oleh Stanislavski dengan gaya akting realisme.
\end{abstract}

Kata kunci: Hikikomori, introvert, magic if, realisme, skizofrenia

\begin{abstract}
My Friend Has Come tells the character I who is very unique both psychologically and sociologically. The character I is an introvert with signs of schizoprenia. In the story, this I is also called as a hikikomori, a nickname in Japanese language to people who isolate themselves from social interaction. To understand and to act as character I, the writer does qualitative research by studying relevant literature about psychology, hikikomori, and also watching other references with similar characterization as character I. The writer uses Stanilavski's method of Magic If with realism acting style.
\end{abstract}

Key words: Hikikomori, introvert, magic if, realism, schizophrenia

\section{Pendahuluan}

Pertunjukan My Friend Has Come yang dibawakan oleh kontingen dari Filipina dengan gaya akting realisme. Penonton dapat merasakan apa yang dirasakan oleh tokoh Aku dan tokoh Temanku. Pertunjukkan My Friend Has Come dikemas sederhana dengan setting tembok khas rumah Jepang serta tatami di tengah ruangan. Pertunjukan sangat memperhatikan dinamika permainan, selain itu naskah $M y$ Friend Has Come menampilkan adegan adegan yang menonjolkan keunikan psikologi tokoh Aku. Adegan pada pertunjukan ini banyak memperlihatkan dengan jelas gejala gangguan jiwa yang diderita tokoh Aku. Salah satu contohnya di adegan awal ketika tokoh Aku terganggu dengan suara air yang terdengar olehnya.
Serta pada adegan terakhir dari pertunjukan terlihat tokoh Temanku menuntun sepeda bersama tokoh Aku kemudian Tokoh aku kembali masuk dan tetap membawa sepeda tanpa siapa - siapa di sampingnya.

Selain itu, penulis merasa ada keistimewaan serta tantangan tersendiri ketika naskah yang akan dipentaskan belum pernah dilakukan sebelumnya dalam bahasa Indonesia. Naskah My Friend Has Come atau dalam bahasa Jepang Tomodachi ga kita adalah karya dari Toshiro Suzue yang ditulis pada tahun 1994. My Friend Has Come sendiri adalah terjemahan dalam bahasa Inggris yang diterjemahkan oleh James Yaegashi. Toshiro Suzue adalah salah satu penulis naskah kenamaan di Jepang. Ia telah menulis beberapa naskah teater. 
Sebagai seorang aktor pertunjukkan teater ini sangat cocok untuk menaikkan kemampuan seorang aktor. Secara tekstur, naskah My Friend Has Come mempunyai dialog, mood atau suasana, serta spectacles yang sangat menguntungkan aktor dalam berperan. Alur yang bercampur antara waktu sekarang serta lampau menjadi pengiring yang tepat untuk menggambarkan hubungan tokoh Aku dan Temanku sebelum kematian tokoh Temanku.

Secara empiris naskah My Friend Has Come mengingatkan penulis dengan mendiang ibu. Setelah satu tahun sepeninggalan ibu, penulis terkadang tidak sadar mengucapkan kalimat "Ibu, mana?". Penulis memiliki harapan untuk dapat berbicara dengan mendiang ibu. Penulis membayangkan betapa berharganya jika penulis bisa dapat dengan mudah berkomunikasi dengan orang yang sudah meninggal. Harapan inilah yang menjadi kekuatan besar untuk mendorong penulis mementaskan naskah My Friend Has Come. Menurut teori Ekspektasi dari Vroom, perilaku yang diharapkan dalam suatu kegiatan akan meningkat apabila seseorang merasakan adanya hubungan yang positif antara usaha-usaha yang dilakukannya dengan hasil yang ditimbulkan (Simamora, 1999). Ingatan empiris ini juga yang penulis gunakan sebagai kekuatan dalam memerankan tokoh Aku. Didukung empiris yang kuat penulis menjadikan pementasan My Friend Has Come sebagai hadiah kecil untuk mendiang ibu. Itulah sebabnya tokoh $A k u$ layak dijadikan studi keaktoran.

Dari latar belakang yang telah dijelaskan, adapun rumusan penciptaannya;

a. Bagaimana memahami dan menemukan karakter seorang penderita skizofrenia dari tokoh Aku?

b. Bagaimana memerankan tokoh Aku dengan gaya akting Realisme?

Adapun tujuan penciptaan dari pemeranan tokoh Aku dalam naskah $M y$
Friend Has Come karya Toshiro Suzue adalah dapat memerankan tokoh Aku dengan melakukan hal - hal di bawah ini:

a. Untuk memahami dan menemukan mengenai penyakit kejiwaan skizofrenia yang diderita tokoh Aku dalam naskah My Friend Has Come.

b. Untuk memerankan tokoh Aku dengan gaya akting realisme.

\section{Tinjauan Pustaka}

Aktor mengekpresikan dirinya melalui tokoh yang dimainkannya. Ketika seorang aktor mempersiapkan diri untuk sebuah pementasan, yang dilakukannya adalah usaha untuk mendefinisikan kembali atau definisi baru dari pementasan tersebut (Sitorus, 2003). Aktor mendefinisikan kembali pementasan My Friend Has Come dengan caranya sendiri melalui pemahaman dan proses latihan yang dilalui.

Aktor yang baik akan menggunakan metode yang tepat untuk dapat memerankan tokohnya. Magic if adalah konsep yang diperkenalkan oleh Stanislavksi. Konsep ini berpusat pada pertanyaan "Jika aku adalah dia (tokoh), apa yang akan aku lakukan?" (Stanislavski, 1980). Sehingga aktor saat memerankan tokoh Aku memposisikan dirinya sebagai tokoh yang akan diperankan. Bagaimana tokoh bersikap pada situasi yang dihadapi. Aktor bertanya pada diri aku apa yang akan dilakukan tokoh Aku pada situasi yang dihadapi oleh tokoh.

Untuk dapat memerankan tokoh, aktor harus dapat jujur dalam arti benar, logis, dan juga masuk akal sesuai dengan tokoh yang diperankan?" (Stanislavski, 1980). Jujur dalam hal ini adalah aktor memerankan tokoh Aku sesuai dengan logika, perasaan dan akal dari tokoh yang diperankan.

Pendekatan presentasi mengutamakan identifikasi antara jiwa si aktor dengan jiwa si karakter, sambil 
memberi kesempatan kepada tingkah laku untuk berkembang. Tingkah laku yang berkembang ini berasal dari situasi - situasi yang diberikan si penulis naskah. Si aktor percaya bahwa aksi dan situasi - situasi yang diberikan, bentuk akan dihasilkan. Dia mengetahui bahwa ekspresi aksi - aksi karakter tergantung dari identifikasi dengan pengalaman pribadinya sendiri (Stanislavksi menyebutnya dengan istilah magic if) (Sitorus, 2003).

Pendekatan presentasi memerlukan pemahaman antara perbedaan jiwa tokoh Aku dan jiwa aktor, perbedaan antara sifat dan laku tokoh Aku dengan aktor. Pemahaman perbedaan ini tidak menutup pengembangan dari untuk memainkan aktivitas - aktivitas yang berada di dalam naskah. Seorang aktor harus bisa memerankan tokohnya dengan merasakan dan memahami situasi yang dialami tokoh yang diperankan dengan teliti. Meletakkan diri dalam posisi tokoh tersebut, melihat melalui sudut pandang tokoh, serta menjadi bagian dari situasi yang ada (Stanislavski, 1980).

Untuk dapat memerankan tokoh Aku yang diperlukan adalah pemahaman atas bagaimana tokoh $\mathrm{Aku}$ bertindak, berpikir, dan merespon situasi di mana ia berada. Sehingga penjabaran di atas dirasa cukup mampu untuk menjadi landasan untuk memerankan tokoh Aku dalam pementasan My Friend Has Come. Selain itu, gaya akting realisme juga akan digunakan dalam memerankan tokoh Aku. Gaya akting realisme adalah salah satu gaya yang diperkenalkan oleh Stanislavski. Gaya akting realisme lebih mengacu pada karakter tokoh, meliputi jiwa, pikiran yang nantinya juga berdampak pada tubuh aktor. Gaya akting yang yang mempunyai alasan kuat dari setiap laku yang dilakukan. Representasi dari sikap pada realitas yang ada dan di tampilkan diatas panggung dengan mengikuti kaidah - kaidah diatas panggung.

\section{Metode Penciptaan}

Metode penciptaan bertujuan untuk dapat maksimal dalam menghasilkan pertunjukkan dengan segala unsur unsurnya. Metode penciptaan dalam karya My Friend Has Come adalah sebagai berikut:

1. Analisis Tokoh Aku

Tahapan ini bertujuan untuk mengetahui serta membahas tokoh Aku yang akan dimainkan dalam karya $M y$ Friend Has Come. Tahapan sebelum menganalisis tokoh Aku, dibutuhkan penerjemahan naskah ke dalam bahasa Indonesia sehingga untuk tahapan reading akan lebih lancar. Dalam karya My Friend Has Come, tokoh Aku adalah pemuda Jepang yang memiliki karakter introvert serta memiliki kecenderungan skizofrenia sehingga dibutuhkan pemahaman mengenai kedua hal tersebut. Cara yang digunakan untuk mengetahui dan memahami karakter introvert serta skizofrenia adalah dengan membaca buku - buku, mencari artikel di internet begitu juga jurnal yang membahas dua hal tersebut serta menonton film atau drama yang memiliki tokoh dengan karakteristik introvert serta skizofrenia. Selain kecenderungan pada dua karakter di atas, untuk dapat menganalisis tokoh Aku, penulis juga wajib mengetahui kebiasaan kebiasaan orang Jepang, terutama ketika tokoh Aku memiliki rumah dengan tatami serta bergabung dalam klub kendo.

2. Proses Latihan Dasar

"Alat aktor adalah tubuh/raga dan jiwa/sukma-nya. Itulah yang harus terus menerus diasah dan dilatih agar siap dalam menghadapi, menggali, dan memainkan peran" (Riantiarno, 2011). Berdasarkan kutipan tersebut, dibutuhkan latihan tubuh serta jiwa aktor secara terus menerus serta membutuhkan metode yang tepat. Latihan 
dasar meliputi tiga hal yang harus dilatih, yaitu;

\subsection{Olah Vokal}

Olah vokal bertujuan untuk melatih suara, daya ucap, daya penyampaian (artikulasi), nada bicara (intonasi) agar karakter tokoh Aku dapat tercipta dan dimainkan dengan baik.

2.2.Olah Tubuh

Olah tubuh dimulai dengan melatih matriks - matriks kecil seperti mata, jari, ekspresi minor. Matriks adalah bagian bagian kecil dari tubuh seperti gerakan persendian jari, perubahan pupil mata, gerakan pada rahang, kembang kempis hidung, dan gerakan kecil pada bagian bagian tubuh lainnya.

Kedua melatih ketahanan tubuh atau stamina dengan cara jogging, bersepeda, dan climbing, serta ditambah dengan gerakan - gerakan aerobik, yoga, dan dasar gerakan taichi.

Karya My Friend Has Come memiliki adegan yang membutuhkan teknik kendo, sehingga dalam latihan dasar tubuh harus mempelajari dan melatih teknik teknik kendo. Mempelajari teknik dasar seperti kuda - kuda, posisi bertahan, dan posisi menyerang.

\subsection{Olah Rasa}

Olah rasa dimulai dengan nafas yang tenang, duduk bersila dan memejamkan mata lalu memusatkan pikiran. Merasakan semua hal yang ada disekitar, dari suara, sentuhan, dan perasaan. Tahap selanjutnya dengan tujuan menambah kepekaan rasa adalah menonton film - film yang memiliki cerita dan aktor aktor yang baik dan benar.

Pada tahapan selanjutnya, proses latihan dilakukan aktor untuk dapat menggunakan gaya akting realism.

\subsection{Pementasan}

Tahapan pentas merupakan tahapan yang akan menampilkan seluruh proses, teknik, dan juga metode yang dilakukan dalam menciptakan karakter tokoh Aku serta dapat menggunakan gaya akting realisme dengan baik. Karya My Friend Has Come akan tersaji utuh lengkap dengan unsur pendukung lainnya seperti lighting, musik, kostum, makeup dan setting.

\subsection{Kesimpulan dan Saran}

Tahapan ini memungkinkan saran dan juga kesimpulan tentang keseluruhan pertunjukkan My Friend Has Come. Tahap ini akan memberikan masukan tentang kelebihan serta kekurangan dari karya ini sehingga dapat menjadi acuan untuk menciptakan karakter tokoh dari pertunjukkan teater dengan gaya akting realisme.

\section{Pembahasan Penokohan Aku}

Menurut Jakob Sumardjo dan Saini K.M dalam bukunya Apresiasi Kesustraan, terdapat beberapa cara untuk dapat memahami tokoh dalam naskah, antara lain melalui perbuatannya, ucapannya, gambaran fisik tokoh, pikiran - pikiran, serta penggambaran langsung (1994). Analisis tokoh dalam naskah bertujuan agar aktor dapat memahami situasi, kondisi yang dialami oleh tokohnya dalam naskah. Tokoh Aku akan dijabarkan melalui tiga dimensi tokoh yaitu dimensi fisiologis, psikologis, dan sosiologis sebagai berikut (Waluyo,2003):

1. Fisiologis

Dalam hal ini, fisiologis berkaitan dengan tubuh dari karakter. Analisis fisiologis adalah pengamatan karakteristik pada tubuh tokoh Aku. Hal - hal berkenaan dengan kondisi fisik tokoh akan dideskripsikan sebagai berikut;

\subsection{Usia}

Usia tokoh Aku berkisar $18-19$ tahun, umur saat dimana pemuda di Jepang memasuki universitas di tahun - tahun pertamanya. Seperti yang dinyatakan tokoh Aku dalam naskah. 1.2.Jenis Kelamin 
Jenis kelamin dari tokoh Aku adalah laki - laki. Hal ini tertulis dalam beberapa adegan.

Pada adegan ini bisa disimpulkan bahwa tokoh Aku adalah laki - laki. Selain itu, tokoh aku juga dekat dengan gadis di sekolahnya yang bernama Hiromi.

\subsection{Ciri Fisik Tokoh Aku}

Ada ciri - ciri fisik dari tokoh aku yang merupakan identitas kuat dari fisiknya. Tokoh Aku mempunyai tinggi badan layaknya pria Jepang pada umumnya sekitar $170 \mathrm{~cm}$. Postur tubuh tokoh Aku sedikit membungkuk dikarenakan saat jalan tokoh Aku lebih sering menunduk.

Rasa rendah diri pada tokoh Aku juga mempengaruhi tubuhnya. Persepsi tokoh $\mathrm{Aku}$ tentang dirinya dipengaruhi bagaimana orang sekitarnya mempengaruhinya. Seperti pada dialog diatas, anggota klub kendo menjadikannya karung tinju membuatnya merasa lemah dan tidak berdaya. Hingga akhirnya bagaimana ia berdiri dan duduk pun akan terpengaruhi oleh pandangan orang lain terhadapnya.

Tokoh Aku yang introvert juga akan menunjukkan postur atau posisi tubuh yang berbeda dengan orang yang ekstrovert. Introvert akan cenderung menutup dirinya seperti menunduk di keramaian. Selain tubuh yang cukup membungkuk, tokoh Aku mempunyai tahi lalat yang tidak terlalu tampak di dahinya.

\section{Psikologis}

Analisis psikologis tokoh dalam naskah adalah kegiatan mengamati tokoh dengan menggunakan pendekatan kejiwaan. Psikologi adalah ilmu yang mempelajari tentang perilaku manusia baik yang terlihat maupun yang tidak terlihat. Sehingga, yang dimaksud dengan analisis psikologis tokoh Aku adalah meneliti perilaku dari tokoh.

Setiap pribadi memiliki tidak hanya karakter introvert namun ekstrovert, hanya akan ada dominasi dari salah satunya. Untuk
Tokoh Aku, dapat dikatakan bahwa karakter introvert lebih dominan dalam dirinya.

Tokoh Aku dapat dikatakan memiliki kelainan kejiwaan yaitu skizofrenia. Skizofrenia adalah keadaan dimana pecahnya proses mental dalam otak seseorang. Terdapat disharmoni pada proses berpikir, perasaan penderita, serta perilakunya (Maramis, 2005). Menurut buku Psikologi Abnormal, skizofrenia adalah sindrom gangguan kejiwaan yang kompleks dan tidak bisa dihindari dapat mengganggu kehidupan pribadi serta sosial dari penderita (Durand, 2007). Skizofrenia sendiri memiliki beberapa tipe dan juga gejala. Tipe skizofrenia antara lain paranoia, disorganisasi, katatonik, tak terbedakan dan residual.

Dari tipe - tipe tesebut, tokoh Aku termasuk pada karakter skizofrenia residual dimana adanya sisa - sisa episode skizofrenik. Tokoh Aku menunjukkan gejala menarik diri dari lingkungan sosial serta tidak adanya motivasi sehingga memutuskan untuk melakukan hikikomori. Selain tipe, gejala skizofrenia terbagi menjadi dua, gejala positif dan negatif. Berdasarkan penjelasan dari Institute of Mental Health, berikut adalah beberapa gejala dari skizofrenia, yaitu gejala positif dan gejala negatif ("Schizoprenia", n.d.). Gejala positif dari penderita skizofrenia adalah halusinasi (berupa suara, bau, serta rasa yang sebelumnya tidak pernah dialami), delusi, dan perilaku yang aneh. Sedangkan gejala negatif berupa kesulitan dalam berbicara, menjauhi kehidupan sosial, tidak menunjukkan emosi, apatis, kehilangan fokus, serta kurangnya motivasi. Tokoh Aku berhalusinasi mendengarkan suara - suara yang sebenarnya tidak ada, tokoh Aku mengalami gejala positif dari skizofrenia.

\section{Sosiologis}

Analisis sosiologis dilakukan dengan mengamati kondisi sosial dari tokoh Aku. 
Dalam kehidupan sosialnya tokoh Aku merupakan manusia yang tidak begitu aktif dalam lingkungan sosial. Kehidupan sosial tokoh Aku akan dipaparkan sebagai berikut:

\subsection{Latar belakang sosial}

Tokoh Aku adalah orang Jepang. Hal ini tentu saja disimpulkan dari bahwa naskah ini adalah naskah Jepang. Lebih detailnya, tokoh Aku adalah orang Jepang yang tinggal di bagian Selatan, tepatnya Osaka.

3.2.Pendidikan

Tokoh Aku adalah orang yang cukup berpendidikan. Ia adalah mahasiswa baru jurusan teknik sipil di sebuah Perguruan Tinggi di Osaka, Jepang.

\subsection{Kegiatan Klub Kendo}

Tokoh Aku digambarkan dalam dialog - dialognya pada naskah mengikuti atau tergabung dalam klub kendo yang ada baik di sekolahnya dulu juga pada saat ia sudah menjadi mahasiswa. Saat perguruan tinggi tokoh Aku mengikuti klub kendo, namun keluar karena dia kalah dengan banyak anggota lainnya yang sudah bersabuk hitam. Dari pemaparan analisis sosiologis pada tokoh $\mathrm{Aku}$, tokoh $\mathrm{Aku}$ adalah individu yang tidak aktif secara sosial.

\subsection{Hikikomori}

Hikikomori adalah sebutan yang diberikan oleh masyarakat Jepang kepada pemuda pemudi Jepang yang menarik diri dari segala kegiatan serta interaksi sosial, dan memilih untuk mengurung diri di dalam kamar (Kremer, 2013). Menurut Tamaki Saito kepada BBC, seorang psikiater asal Jepang, terdapat variasi gejala dari pemuda yang melakukan hikikomori, antara lain kemarahan meluap layaknya anak kecil kepada orang tua, paranoia, obsesi terhadap suatu hal dan juga depresi (Kremer, 2013).

Dalam perilaku tokoh Aku, hikikomori yang dilakukkannya pasca meninggalnya tokoh Temanku. Penarikan dirinya dari dunia sosial ini tidak berlangsung serta merta melainkan secara bertahap. Aku memutuskan untuk tidak meninggalkan rumah dan menarik diri dari interaksi sosialnya selain persoalan lain yang dialami tokoh Aku sebagai individu yang introvert. Perasaan bersalah atas meninggalnya tokoh Temanku juga menjadi penyebab depresi pada tokoh Aku. Perasaan bersalah karena tidak dapat menolong tokoh Temanku menghantui tokoh Aku.

\section{Hubungan Fungsional Tokoh Aku}

Hubungan fungsional tokoh Aku berkaitan dengan segala komponen yang ada di dalam naskah My Friend Has Come. Pada bagian ini akan dipaparkan komponen dalam naskah dan bagaimana hubungan dan fungsinya terhadap keberadaan tokoh Aku di dalam pertunjukan My Friend Has Come. 4.1.Hubungan Tokoh Aku dengan Alur

Alur dalam pementasan adalah rangkaian atau susunan peristiwa (Sembungan, 1983). Alur pada pementasan My Friend Has Come adalah alur campuran. Terdapat adegan di mana tokoh Aku mereka kejadian di masa lalu ketika dia masih di Sekolah Menengah Atas. Tokoh Aku bertindak sebagai penggerak alur pada pementasan My Friend Has Come ini, tokoh Aku berada dalam setiap adegan. Selain itu tokoh Aku juga penghubung antar adegan di masa sekarang dan juga masa lalu. Hal ini menunjukkan bahwa tokoh Aku merupakan tokoh penting dalam pementasan ini.

4.2.Hubungan Tokoh Aku dengan Latar

Tokoh Aku juga berpengaruh kepada latar waktu dan tempat dari pementasan $M y$ Friend Has Come. Latar tempat adalah rumah tokoh Aku pada saat musim Panas. Rumah tradisional Jepang yang lantainya beralaskan tatami.

4.3.Hubungan Tokoh Aku dengan Suasana

Suasana yang ditampilkan dalam pementasan My Friend Has Come adalah kesepian, kegembiraan, kebingungan, serta kecanggungan yang muncul antara tokoh Aku dan tokoh Temanku. Suasana kesepian 
terlihat saat adegan pertama ketika tokoh $\mathrm{Aku}$ sendiri, berbicara pada semut, dan menghabiskan waktu liburan musim Panas di dalam rumah. Suasana kegembiraan, kebingungan juga kecanggungan muncul ketika tokoh Temanku datang menggunakan sepeda. Aku mengungkapkan kegembiraannya atas kedatangan tokoh Temanku. Dalam kegembiraannya, tokoh Aku juga mengungkapkan kebingungannya atas kedatangan tokoh Temanku.

4.4.Hubungan Tokoh Aku dengan Tokoh Temanku

Tokoh Aku dan Temanku memiliki kedekatan terlihat dari beberapa dialog yan menyatakan bahwa mereka teman lama. Tokoh Aku dan Temanku memiliki hubungan sebab akibat, tokoh Aku mendapati dirinya membayangkan kedatangan tokoh Temanku yang diperkirakan meninggal satu minggu yang lalu. Perasaan kesepian yang hadir membuat tokoh Aku berhalusinasi atas kedatangan Temanku. Begitu juga tokoh Temanku, tokoh Aku merupakan penghubungnya dengan masa lalu. Tokoh Aku gembira atas kedatangan tokoh Temanku. Terdapat akibat dari kedatangan tokoh Temanku pada tokoh Aku. Keberadaan tokoh Aku cukup penting bagi tokoh Temanku sehingga Ia ingin diingat oleh tokoh Aku. Sepanjang naskah My Friend Has Come, hubungan sebab akibat kedua tokoh tergambar dari dialog dan juga adegan yang ditampilkan.

\section{Pemanggungan}

\subsection{Performance}

Pertunjukan atau performance adalah tahapan akhir dalam memerankan tokoh Aku dalam naskah My Friend Has Come. Pada tahapan ini aktor yang memerankan tokoh Aku dan juga tokoh Temanku beserta aspek pementasan lainnya akan menjadi satu sebagai pementasan yang utuh. Pemeranan tokoh Aku akan diwujudkan pada Jum'at, 5 Januari 2018 pada pukul 19.30 WIB di
Ruangan Bawah dari Jogja Contemporary yang bertempat di dalam Kompleks Jogja National Museum.

Untuk dapat memerankan tokoh Aku dalam pementasan My Friend Has Come ini dibutuhkan aspek - aspek pendukung yang akan dijelaskan sebagai berikut.

\subsection{Setting}

Setting pada pementasan My Friend Has Come menggambarkan suasana rumah Jepang dengan tembok, tatami, dan juga meja. Tembok kayu dengan kertas khas rumah tradisional Jepang akan berada di bagian belakang panggung. Lalu, di depan tembok atau di tengah ruangan akan dipasang tatami atau tikar khas Jepang. Di atas tatami akan di letakkan meja kotak dengan tinggi $30 \mathrm{~cm}$. Ruangan ini terbuka menghadap ke halaman belakang atau tempat duduk penonton.

Dalam proses ini penulis mengalami hambatan pada proses pembuatan setting dikarena ketidak disiplinan yang dilakukan oleh pimpinan tim artistik sehingga terjadi keterlambatan yang membuat pembiasaan terhadap setting terjadi keterlambatan.

\subsection{Pemanggungan}

Penulis memilih Jogja Contemporary sebagai tempat pentas bertujuan untuk membuat keintiman antara penulis dengan penonton dan penonton dengan penonton lainnya. Ruang yang biasanya digunakan untuk pameran seni rupa di manipulasi dengan menambahkan stage kecil. Ruang yang tidak terlalu besar, sekitar $7 \times 10 \mathrm{~m}^{2}$ membuat penonton dan pertunjukan menjadi lebih dekat. Jarak antara stage dan penonton berkisar $2 \mathrm{~m}$. Dalam hal ini, penulis berharap dapat membuat interaksi yang lebih intens. Interaksi yang dimaksud bukanlah berdialog dengan penonton, melainkan emosi pemain yang dapat dirasakan oleh penonton.

Untuk menjaga blocking adegan bersepeda tokoh Temanku dengan area yang terbatas tersebut, penulis membuat area di 
sekeliling penonton menjadi bagian dari panggung. Sehingga, saat adegan bersepeda, tokoh Temanku mengayuh mengitari penonton.

Ruangan yang kecil tersebut juga membuat udara dalam ruangan pertunjukan lebih panas meskipun terdapat pendingin udara. Penulis memutuskan untuk memanfaatkan keadaan ini, sebagai bagian dari pertunjukan. Penonton merasakan hawa panas seperti yang dirasakan tokoh Aku dan Temanku dalam pertunjukan My Friend Has Come. Situasi ini adalah salah satu bentuk interaksi antara pertunjukan dan penonton.

\subsection{Properties}

Terdapat beberapa properties dalam pementasan My Friend Has Come, antara lain adalah sepeda dengan keranjang di depannya yang akan dinaiki oleh Temanku. Merupakan sepeda yang biasa digunakan oleh orang Jepang untuk pergi ke satu tempat ke tempat lain. Kipas kertas juga digunakan dalam pementasan, kipas khas Jepang yang biasa digunakan. Gelas kaca 2 buah akan digunakan untuk adegan saat meminum teh barley. Lalu, selain itu kamera juga akan digunakan pada adegan 9 saat tokoh Aku dan Temanku berfoto bersama.

\subsection{Lighting}

Pencahayaan atau disebut juga lighting memiliki peran penting dalam memberikan informasi kepada penonton tentang suasana yang terjadi di dalam pementasan. Dalam pementasan My Friend Has Come cahaya yang digunakan adalah lampu general yang menerangi seluruh panggung. Selain itu akan digunakan juga lampu fokus untuk beberapa adegan dalam pementasan seperti pada Adegan 5 ketika tokoh Aku memperagakan kejadian di ruang klub kendo.

\subsection{Makeup}

Dalam pementasan, makeup berperan untuk memberikan identitas kepada tokoh. Untuk pementasan My Friend Has Come tidak menggunakan makeup yang spesifik, hanya menggunakan bedak mengingat jarak dengan penonton yang cukup dekat. Selain itu, tato penulis juga ditutup menggunakan foundation dan bedak.

\subsection{Kostum}

Kostum yang digunakan tokoh Aku dalam pementasan My Friend Has Come ini cukup sederhana. Busana yang biasa digunakan pemuda Jepang di saat musim Panas yaitu berupa celana linen dan kaos berwarna gelap. Sedangkan untuk tokoh Temanku menggunakan kaos singlet dan kemeja putih susu dengan motif naruto (potongan rebung) serta celana kain dan sepatu capung.

\subsection{Illustration}

Illustration juga merupakan salah satu aspek yang mendukung suasana dalam pementasan. Dengan ilustrasi musik, suasana pada adegan dalam pementasan dapat terwujud. Ilustrasi musik yang digunakan dalam pementasan My Friend Has Come adalah sebagai berikut; 1) Suara tengkerek saat Musim Panas, 2) Alunan musik Noh, 3) Lagu Kizuna dari Orange Range dengan aransemen instrumen tradisional Jepang Shamishen dan Shakuhachi.

\section{Tata Pentas}

Dalam proses pemeranan tokoh Aku dalam naskah My Friend Has Come terdapat beberapa hambatan yang dialami oleh penulis antara lain;

1. Disiplin

Masalah kedisiplinan menjadi hambatan utama dari proses pemeranan tokoh Aku. Jadwal latihan seharusnya dimulai pukul 8 malam setiap Selasa, Kamis, dan Sabtu namun karena ketidaksiplinan aktor, latihan dimulai pukul 10 malam. Keterlambatan setiap latihan ini membuat latihan tidak efektif. Dengan memulai latihan lebih malam, latihanpun selesai di pagi hari. Latihan terlalu larut juga menjadi tidak efektif karena pikiran dan 
tubuh aktor terkadang sudah tidak fokus atau kehilangan konsentrasi dalam latihan.

Selain itu beberapa capaian - capaian tidak diselesaikan sesuai jadwal yang sebelumnya ditentukan. Capaian ini antara lain adalah penghapalan dialog. Naskah seharusnya sudah selesai dihapal oleh aktor pada bulan Oktober. Namun, dikarenakan ketidakdisplinan aktor latihan tanpa membaca naskah baru dilakukan di bulan Desember.

Capaian selanjutnya yang mengalami keterlambatan adalah penggunaan teknis kendo. Pertarungan kendo yang dilakukan pada adegan 4 dan 8 mengalami hambatan dikarenakan aktor tidak berlatih teknis kendo cukup lama. Namun, olah tubuh yang dilakukan oleh aktor sebelumnya mempersiapkan aktor untuk berlatih dalam waktu yang relatif lebih singkat. Hambatan ini tidak hanya dialami oleh aktor, namun juga lawan main dalam pementasan ini.

\section{Koordinasi Setting}

Hambatan yang dialami penulis dalam proses pemeranan tokoh Aku adalah penggarapan setting. Terdapat kurangnya koordinasi dengan tim setting membuat hasil setting tidak sesuai penggambaran penulis. Tidak adanya komunikasi dari tim setting kepada tim lain serta aktor menyulitkan proses pementasan ini. Tim settings tidak memberikan perkembangan pembuatan setting sehingga penulis tidak dapat memperkirakan kekurangan serta kebutuhan setting dalam mendukung pementasan $M y$ Friend Has Come.

\section{Properties}

Dalam proses ini, pencarian properti yang akan digunakan dalam pementasan juga mengalami kesulitan. Menentukan property yang tepat yang bisa mendukung pementasan sangat dibutuhkan. Pada awal proses terdapat tiga properti yang digunakan yaitu kipas, teh barley dan gelas, sepeda, dan kamera. Namun dalam perkembangan dan pencarian tokoh Aku, aktor menemukan kebutuhan properti lainnya seperti Walkman, komik, dan makanan kecil yang akan digunakan dan direspon aktor di atas panggung.

\section{Simpulan}

Dalam menjalani proses pertunjukam My Friend Has Come karya Toshiro Suzue terdapat banyak sekali kendala yang dialami. Baik secara teknis ataupun non teknis. Penulis mencoba berbagai metode yang dapat membantu penulis menemukan tokoh $\mathrm{Aku}$ dan dapat memerankannya dengan baik. Metode pada dasarnya tidak bersifat pasti karena dalam menerapkan beberapa metode penulis mengalami kendala yang cukup serius dan beberapa lagi membuat penulis terjebak dalam metode yang tidak memberikan keberhasilan yang signifikan dalam mendalami tokoh. Penulis memasuki tokoh Aku melalui sifatnya yang introvert, kelainan kejiwaan yang tokoh Aku miliki, dan depresi yang dialami dalam proses hikikamori yang yang sedang dilakukan oleh tokoh Aku. Tiga jalur kejiwaan itu yang penulis pilih untuk memerankan tokoh Aku sehingga dalam prosesnya penulis sering terjebak dalam emosi - emosi yang dalam dan berat. Emosi yang selesai pada diri penulis atau dengan kata lain penonton tidak dapat merasakan emosi yang penulis hadirkan karena hanya selesai diatas panggung.

Kendala yang cukup berat untuk penulis adalah merasakan suara air yang berputar, berdering dan berbenturan dalam kepala seperti yang dirasakan tokoh Aku. Salah satu halusinasi yang sering berputar dikepala tokoh Aku, untuk mencapai itu penulis berenang dan menyelam, dan menyalakan air dikamar mandi lalu meninggalkannya. Hal ini penulis lakukan agar dapat merasakan reflek dari suara air yang didengar. Latihan yang cukup penting lainnya adalah kendo. Kendo menjadi sedikit menjadi kendala karena di Yogyakarta saat 
ini sudah tidak ada klub kendo yang akhirnya membuat penulis belajar melalui situs Youtube. Kesulitan dari belajar melalui Youtube adalah susah untuk mengejar teknik secara detail. Hal ini dikarenakan tidak ada yang mengawasi dan memperhatikan gerak yang kurang tepat dalam kendo.

Proses rehearsal adalah proses penerapan dari proses training. Dinamika yang terjadipun menjadi catatan penting dalam proses kreatif mementaskan naskah My Friend Has Come. Kendala yang sering terjadi adalah persoalan gejolak perasaan dan pikiran tokoh Aku yang belum dapat penulis lakukan dengan baik. Sehingga apa yang penulis lakukan hanyalah hafalan teknis yang pernah dilatihkan sebelumnya. Kedisplinan dalam proses juga menjadi kendala yang cukup merepotkan.

Tokoh Aku adalah tokoh yang dipilih dalam penciptaan ini karena tokoh Aku memiliki keunikan karakter yang akan menjadi tantangan bagi penulis yang memiliki karakter yang jauh berbeda dengan tokoh Aku. Keunikan karakter tokoh Aku antara lain adalah seorang individu introvert dengan kecenderungan skizofrenia. Penulis membutuhkan pemahaman yang baik terhadap dua karakteristik tersebut untuk dapat memerankan tokoh Aku dengan baik.

Proses kreatif pada penciptaan tokoh Aku pada pertunjukan teater My Friend Has Come ini menggunakan metode akting realisme dengan pendekatan magic if dari Stanislavksi. Kedua cara tersebut dirasa mampu memahami serta menciptakan tokoh Aku yang memiliki kecenderungan skizofrenia.

Proses penciptaan dan penemuan tokoh Aku yang menderita skizofrenia dilalui dengan beberapa tahapan. Pertama yang dilakukan penulis adalah dengan memahami teks dan juga subteks. Mencari tahu tentang introvert, skizofrenia, hikikomori, serta kebiasaan - kebiasaan tokoh Aku baik yang digambarkan langsung pada naskah My Friend Has Come dan juga pada tinjauan - tinjauan karya serta sumber - sumber informasi lainnya yang menjadi acuan untuk memahami dan menciptakan tokoh Aku. Kedua adalah dengan melakukan serangkaian latihan yang berguna untuk menjaga stamina penulis, mengolah rasa serta vokal yang dapat mewakili dengan baik karakter dari tokoh Aku.

\section{Daftar Pustaka}

Durand, V. M., \& Barlow, D. H. (2007). Intisari Psikologi Abnormal Edisi Keempat. Yogyakarta: Pustaka Pelajar.

Kremer, W. \& Hammond, C. (2013, July 13). Hikikomori: Why are so many Japanese men refusing to leave their homes?. Retrieved December 10, 2017 from http://www.bbc.com/news/magazine23182523

Maramis, W. F. (2005). Catatan Ilmu Kedokteran Jiwa. Surabaya: Airlangga University Press.

Riantiarno, N. (2011). Kitab Teater. Jakarta: Gramedia Widiasarana Indonesia.

Sembungan, W. F. (1983). Pengetahuan Tentang Bentuk - Bentuk Lakon. Bandung: Persada Pustaka.

Simamora, H. (1999). Manajemen Sumber Daya Manusia. Jakarta.

Sitorus, Eka D. (2003). The Art of Acting "Seni Peran untuk Teater, Film dan $T V$ ”, Jakarta: PT. Gramedia Pustaka Utama.

Stanislavksi, K. (1980). Persiapan Seorang Aktor (A. Sani, Trans). Jakarta: Pustaka Jaya.

Sumardjo, J. \& Saini, K.M. (1994). Apresiasi Kesustraan. Jakarta: Gramedia.

Waluyo, H. J. (2003). Drama Teori dan Pengajarannya. Yogyakarta: Hanindita Graha. 